\title{
Gluten-Free Bread Enriched with Vegetable Flours
}

\author{
Maria A. Saccotelli, Sara Spinelli, Amalia Conte*, Matteo A. Del Nobile \\ Department of Agricultural Sciences, Food and Environment, University of Foggia, Foggia, Italy \\ Email: *amalia.conte@unifg.it
}

How to cite this paper: Saccotelli, M.A., Spinelli, S., Conte, A. and Del Nobile, M.A. (2018) Gluten-Free Bread Enriched with Vegetable Flours. Food and Nutrition Sciences, 9, 356-368. https://doi.org/10.4236/fns.2018.94028

Received: November 23, 2017

Accepted: April 25, 2018

Published: April 28, 2018

Copyright (๑) 2018 by authors and Scientific Research Publishing Inc. This work is licensed under the Creative Commons Attribution International License (CC BY 4.0).

http://creativecommons.org/licenses/by/4.0/

(c) (i) Open Access

\begin{abstract}
The effects of different vegetable flours (broccoli, cauliflower, artichoke, fennel, zucchini and mushroom) added to gluten-free bread on sensory quality, antioxidant properties and glycemic response were assessed. Among the vegetable flours, the addition of fennel flour significantly improved sensory bread quality. Artichoke flour has the highest phenolic $(26.51 \pm 1.92 \mathrm{mg} / \mathrm{g} \mathrm{dw})$ and flavonoid content $(26.43 \pm 1.93 \mathrm{mg} / \mathrm{g} \mathrm{dw})$. Even though the content of total phenol and flavonoids in vegetable flours was higher when compared to supplemented bread, the addition of artichoke and zucchini flours increased the total phenolic and flavonoid content and improved antioxidant activity. The incorporation of high level of vegetable flours (15\%) also decreased the glycemic index of bread, in particular with artichoke and zucchini flours (59 \pm 1.21 and $62 \pm 0.49$, respectively). To sum up, the results are very interesting because the addition of vegetable flours into gluten-free bread can improve nutritional and sensory properties of bread.
\end{abstract}

\section{Keywords}

Gluten-Free Bread, Vegetable Flours, Antioxidant Activity, Glycemic Response

\section{Introduction}

Nowadays, there is a growing interest in gluten-free products as celiac disease is increasing. Many commercially available gluten-free breads are of lower quality than their counterparts containing gluten [1]. The formulation of gluten-free bakery products presents a major challenge for the food industry. The main defects of gluten-free bread consist in a low quality, unstable structure, friable and dry crumb, lack of aroma and mouth feel [2]. In numerous studies, various technological parameters and formulations were studied to improve the quality 
of gluten-free bread using starches [1], dairy products, gums and hydrocolloids [3]. Rice flour is one of the most suitable cereal flour for gluten-free products because it has a low level of prolamine and possesses unique nutritional, hypoallergenic, colorless, and bland taste properties [4]. Gluten-free bread is also poor from a nutritional point of view. The addition of compounds from fruit and vegetables are considered good ingredients to increase healthy properties [5] [6]. Recent studies have shown that herbal fortification of white bread could be considered a new trend to improve its nutritional value [7], being vegetable products rich in bioactive compounds (carotenoids, vitamins, phenolic compounds) and dietary fibers. No studies have been found on gluten-free bread enriched with vegetables. Therefore, the objective of this study was to determine the effect of different forms of fortification by using various vegetable flours. Both sensory and chemical properties were investigated to assess the product quality.

\section{Materials and Methods}

\subsection{Raw Materials and Chemicals}

Commercial corn-starch was obtained from Farmalabor s.r.l. (Canosa di Puglia, Italy), rice flour was purchased from Agostini Mill (Montefiore dell'Aso, Italy), potato starch, compressed fresh yeast, sugar, salt and sunflower oil were bought from local market. The whey protein isolate (WPI) was provided from Perrin's Chemicals s.a.s. (Bari, Italy), baking soda, cream of tartar and guar seed flour were supplied from Farmalabor s.r.l. (Canosa di Puglia, Italy).

The investigated vegetables, broccoli, cauliflower, artichoke, fennel and zucchini were provided by Farris farm (Troia, Foggia, Italy), mushroom were purchased from Ermes s.n.c. (Noicàttaro, Bari, Italy). The samples were dried at $35^{\circ}$ $\mathrm{C}$ in a dryer (SG600, Namad, Roma, Italy) for 48 hours. The dried vegetable was reduced in a fine powder by a hammer mill (16/BV-Beccaria s.r.l., Cuneo, Italy) and then was sieved with a Retsch Vibratory Sieve Shaker AS 300 (Haan, Germany) to obtain a median particle size less than $63 \mu \mathrm{m}$.

All chemical reagents (analytical grade) were supplied from Sigma-Aldrich (Milan, Italy).

\subsection{Bread-Making Process}

The reference bread sample (named as B_CTRL) was prepared using the following ingredients: corn starch (330 g), rice flour (300 g), potato starch (300 g), compressed fresh yeast (36 g, previously dissolved in warm water), sugar (60 g), salt (18 g), sunflower oil (18 g), whey protein isolate (WPI) (60 g), baking soda $(18 \mathrm{~g})$, cream of tartar $(36 \mathrm{~g})$, guar seed flour $(12 \mathrm{~g})$ and water $(840 \mathrm{~g})$. The ingredients were first mixed using a mixer (Conti Impastatrici, Verona, Italy) at low speed $(110 \mathrm{rpm})$ for $5 \mathrm{~min}$, and then at a higher speed $(200 \mathrm{rpm})$ for further $10 \mathrm{~min}$. Thus, the obtained dough was placed in the incubator (Thermogel, Varese, Italy) at constant temperature $\left(30^{\circ} \mathrm{C}\right)$ and $\mathrm{RH}(85 \%)$. After $90 \mathrm{~min}$, the dough was divided into pieces of $670 \mathrm{~g}$, shaped in apposite moulds and placed in 
incubator for further $60 \mathrm{~min}$. Finally, after second proofing, the samples were baked in a pre-heated electric oven (Europa Forni, Vicenza, Italy) at $230^{\circ} \mathrm{C}$ for $10 \mathrm{~min}$, followed by $40 \mathrm{~min}$ at $200^{\circ} \mathrm{C}$. Baking process was performed in triplicate. After baking, breads were cooled to room temperature for $3 \mathrm{~h}$ and sliced 15 $\mathrm{mm}$ thick, removing aseptically the crust.

The other experimental bread samples (B_BROC; B_CAUL; B_ART; B_FEN; B_ZUC; B_MUSH) were prepared by adding $15 \%$ of the respective vegetable flours (F_BROC; F_CAUL; F_ART;_F_FEN; F_ZUC; F_MUSH) to $930 \mathrm{~g}$ of mixture flour (corn starch, rice flour, potato starch) (named as F_CTRL). Before dough making, each vegetable powder was hydrated with an appropriate quantity of water to the desired consistency. All the experimental samples were realized using the same procedure as for the B_CTRL. For chemical analyses, the slices were dried at $35^{\circ} \mathrm{C}$ in a ventilated stove (BINDER GmbH, Tuttlingen, Germany), milled and sieved in order to achieve a fine bread dust $(800 \mu \mathrm{m})$.

\subsection{Bread Sensory Analysis}

Bread sensory properties were carried out with a panel of 8 trained tasters. Before sensory analysis, samples were sliced with an electric slicing knife (thickness of $15 \mathrm{~mm}$ ) (Atlantic, Calenzano, Italy) without removing the crust. Samples were placed on white plates and identified with random three-digit numbers. Bread sensorial quality was determined using a scale from 1 (extremely unpleasant), to 9 (extremely pleasant) based on overall acceptance (color, appearance, odor, taste, crust, crumb firmness and presence of large bubbles).

\subsection{Chemical Analyses}

For chemical analysis, bioactive compounds were extracted in triplicate from samples using a method described by Lim, Park, Ghafoor, Hwang, and Park [8]. Briefly, $1 \mathrm{~g}$ of sample powder was homogenized in $10 \mathrm{ml}$ of aqueous ethanol $\left(80 \%\right.$; $\mathrm{v} / \mathrm{v}$ ) for $2 \mathrm{~h}$ at $37^{\circ} \mathrm{C}$ and centrifuged at $12,000 \mathrm{~g}$ for $15 \mathrm{~min}$. The supernatant was collected and store at $4^{\circ} \mathrm{C}$ prior to analysis.

\subsubsection{Total Phenols, Flavonoids and Antioxidant Activity Determination} Total phenolic compounds were determined by UV-vis spectrophotometric method according to Lim et al. [8] and using gallic acid as standard. The total phenolic content was expressed as $\mathrm{mg}$ gallic acid/g of dry weight (dw).

Total flavonoid content was determined spectrophotometrically using the method of Marinelli, Padalino, Nardiello, Del Nobile, and Conte [9] based on aluminum chloride colorimetric method and using quercetin as standard. The total amount of flavonoids was expressed as $\mathrm{mg}$ of quercetin/g of dry weight $(\mathrm{dw})$.

The antioxidant activity was evaluated using ABTS (2,2'-azino-bis (3-ethylbenzothiazoline-6-sulphonic acid) assay according to the method of Cedola, Cardinali, Del Nobile, and Conte [10] and using Trolox (6-hydroxy2,5,7,8-tetramethylchroman-2-carboxylic acid) as standard. The results ware ex- 
pressed as mg Trolox equivalents for gram of dry weight (dw).

DPPH (2,2-diphenyl-1-picrylhydrazyl) radical scavenging activity was measured according to method of Das et al. [7] with slight modifications. Bread extracts $(100 \mu \mathrm{l})$ were mixed with $250 \mu \mathrm{L}$ of DPPH ethanolic solution $(1 \mathrm{mmol} / \mathrm{l})$ and $2.0 \mathrm{~mL}$ of $80 \%$ ethanol, shaken vigorously and allowed to stand in darkness at room temperature for $20 \mathrm{~min}$. The absorbance was measured at $517 \mathrm{~nm}$ in a spectrophotometer (UV1800, Shimadzu Italia s.r.l., Milano, Italy), using 80\% ethanol as blank. The control solution was constituted by $80 \%$ ethanol instead of the sample. The radical scavenging activity was expressed as the inhibition percentage using the Equation (1), where $A_{\text {control }}$ and $A_{\text {sample }}$ are the absorbance of the control solution and the absorbance of the sample solution, respectively:

$$
\% \text { Inhibition of DPPH }=A_{\text {control }}-A_{\text {sample }} \cdot 100 / A_{\text {control }}
$$

\subsubsection{Available Carbohydrates Determination and In vitro Digestion} The available carbohydrates $(\mathrm{ACH})$ were determined according to the method described in the "Available Carbohydrates and Dietary Fibre" assay kit (Megazyme).

For in vitro digestion, based on the methodology of Mastromatteo et al. [11], the results were expressed as mg of glucose equivalent (GE) per $g$ of sample vs. time $(0-180 \mathrm{~min})$. Anyway, glycemic index was calculated as the incremental area under the curve (iAUC) for the tested products divided by the iAUC of a reference food (white bread) [12].

\subsection{Statistical Analysis}

All the experimental data were subjected to statistical evaluation using a one-way variance analysis (ANOVA). The mean values were compared and grouped by Fisher's least significant difference test at a significance level of $\mathrm{p}<0.05$ using STATISTICA 7.1 for Windows (StatSoft, Inc., Tulsa, OK, USA).

\section{Results and Discussion}

\subsection{Bread Sensory Evaluation}

Results of bread sensory quality are reported in Table 1. Data revealed that all sensory scores were in the range 5 - 8 indicating that breads were acceptable, with some differences among them. In particular, the crumb color of B_ART sample had the lowest score, since the color of the artichoke flour was dark green and interfered with the original color of the control bread. The second lower value was for sample B_ZUC, in fact, also in this case the green color of crumb was less appreciated than the other samples. Specifically, the B_FEN and B_CAUL samples had the highest values, since the corresponding flours had a color that did not interfere with the typical light color of the control bread. For other sensory characteristics (odor and taste), B_FEN sample had the highest value, B_ART was positively assessed, while B_BROC and B_ZUC samples showed the lowest values, due to the perception of a sensation described by the 
Table 1. Sensory characteristics of bread samples.

\begin{tabular}{|c|c|c|c|c|c|c|c|c|}
\hline Sample & Color & Appearance & Odor & Taste & Crust firmness & Crumb firmness & Large bubbles & Overall quality \\
\hline B_CTRL & $7.44 \pm 0.32^{\mathrm{b}}$ & $7.50 \pm 0.27^{\mathrm{b}}$ & $7.25 \pm 0.38^{\mathrm{b}}$ & $7.13 \pm 0.23^{b}$ & $7.44 \pm 0.18^{\mathrm{b}}$ & $7.38 \pm 0.23^{\mathrm{a}, \mathrm{b}}$ & $7.56 \pm 0.42^{\mathrm{a}, \mathrm{b}}$ & $7.50 \pm 0.38^{\mathrm{b}}$ \\
\hline B_BROC & $7.38 \pm 0.35^{\mathrm{b}}$ & $7.13 \pm 0.23^{\mathrm{b}, \mathrm{c}}$ & $6.75 \pm 0.27^{\mathrm{c}}$ & $6.06 \pm 0.32^{\mathrm{d}}$ & $7.19 \pm 0.26^{\mathrm{b}, \mathrm{c}}$ & $6.69 \pm 0.37^{\mathrm{c}}$ & $7.00 \pm 0.38^{\mathrm{c}}$ & $6.50 \pm 0.27^{c}$ \\
\hline B_CAUL & $7.69 \pm 0.37^{\mathrm{a}, \mathrm{b}}$ & $6.88 \pm 0.23^{c}$ & $6.81 \pm 0.46^{\mathrm{c}}$ & $6.25 \pm 0.27^{\mathrm{d}}$ & $6.50 \pm 0.27^{\mathrm{d}}$ & $6.56 \pm 0.42^{c}$ & $6.31 \pm 0.37^{\mathrm{d}}$ & $6.38 \pm 0.23^{\mathrm{c}, \mathrm{d}}$ \\
\hline B_ART & $6.25 \pm 0.27^{c}$ & $6.50 \pm 0.38^{d}$ & $7.38 \pm 0.23^{\mathrm{b}}$ & $6.56 \pm 0.32^{c}$ & $6.63 \pm 0.23^{d}$ & $5.56 \pm 0.32^{\mathrm{d}}$ & $6.25 \pm 0.38^{\mathrm{d}}$ & $6.13 \pm 0.44^{\mathrm{d}}$ \\
\hline B_FEN & $7.94 \pm 0.32^{\mathrm{a}}$ & $8.06 \pm 0.18^{\mathrm{a}}$ & $8.13 \pm 0.23^{\mathrm{a}}$ & $7.56 \pm 0.18^{\mathrm{a}}$ & $7.81 \pm 0.26^{\mathrm{a}}$ & $7.69 \pm 0.26^{\mathrm{a}}$ & $7.75 \pm 0.27^{\mathrm{a}}$ & $7.88 \pm 0.35^{\mathrm{a}}$ \\
\hline B_ZUC & $6.75 \pm 0.27^{\mathrm{b}}$ & $5.50 \pm 0.27^{\mathrm{e}}$ & $5.69 \pm 0.37^{\mathrm{d}}$ & $5.31 \pm 0.37^{\mathrm{e}}$ & $6.56 \pm 0.42^{\mathrm{d}}$ & $5.00 \pm 0.46^{\mathrm{e}}$ & $5.06 \pm 0.32^{\mathrm{e}}$ & $5.13 \pm 0.23^{\mathrm{e}}$ \\
\hline B_MUSH & $7.50 \pm 0.38^{b}$ & $7.19 \pm 0.26^{\mathrm{b}}$ & $6.81 \pm 0.37^{c}$ & $6.13 \pm 0.23^{\mathrm{d}}$ & $7.13 \pm 0.35^{c}$ & $7.25 \pm 0.38^{\mathrm{b}}$ & $7.31 \pm 0.26^{\mathrm{b}, \mathrm{c}}$ & $6.56 \pm 0.18^{c}$ \\
\hline
\end{tabular}

${ }^{\text {a-e }}$ Means $( \pm S D, n=3)$ in the same column followed by different superscript letters differ significantly $(p<0.05)$.

panelists as "herbaceous". In addition, it is worth noting that B_ZUC sample showed a crumb very compact and with a presence of small bubbles, which was most probably due to the lower amount of water added. The second lowest value was for sample B_ART, while, also in this case, B_FEN sample showed the highest value, due to a soft and porous crumb with the presence of large bubbles related to the method of hydration of vegetable flour. Results highlighted that the maximum score of overall quality (more than 7) was obtained by the B_FEN sample, and there were statistically significant differences compared to all other samples including the control. In terms of overall quality, the bread enriched with fennel flour was the most appreciated, since this sample showed the higher scores for all the sensory attributes evaluated.

\subsection{Chemical Quality}

\subsubsection{Total Phenols, Flavonoids and Antioxidant Activity of Flour and Bread}

The total phenolic compounds of flour and bread were expressed as mg gallic acid per gram of dry weight and shown in Table 2. The F_ART sample had the highest phenolic content $(26.51 \pm 1.92 \mathrm{mg} / \mathrm{g} \mathrm{dw})$ followed by F_BROC $(8.22 \pm$ $0.14 \mathrm{mg} / \mathrm{g} \mathrm{dw})$ and F_ZUC samples $(7.80 \pm 0.13 \mathrm{mg} / \mathrm{g} \mathrm{dw})$. Among the vegetable flours, samples F_CAUL, F_MUSH and F_FEN had the lowest phenolic content $(6.43 \pm 0.27 \mathrm{mg} / \mathrm{g} \mathrm{dw}, 6.11 \pm 0.53 \mathrm{mg} / \mathrm{g} \mathrm{dw}$ and $4.54 \pm 0.08 \mathrm{mg} / \mathrm{g} \mathrm{dw}$, respectively) and the differences between them and the control flour $(0.29 \pm 0.00 \mathrm{mg} / \mathrm{g} \mathrm{dw})$ were statistically significant. With respect to bread, the phenolic value was higher in B_ZUC sample $(2.58 \pm 0.02 \mathrm{mg} / \mathrm{g} \mathrm{dw})$ followed by B_ART $(2.50 \pm 0.01$ $\mathrm{mg} / \mathrm{g} \mathrm{dw}$ ), even if F_ART sample showed a value much higher compared to all the other flours. The results were also high, surprisingly, for B_CAUL (2.45 \pm $0.08 \mathrm{mg} / \mathrm{g} \mathrm{dw})$ and B_FEN samples $(2.45 \pm 0.03 \mathrm{mg} / \mathrm{g} \mathrm{dw})$, followed by B_BROC sample $(2.44 \pm 0.04 \mathrm{mg} / \mathrm{g} \mathrm{dw})$. In addition, consistent with the above results, the content of phenols was lower in the B_CTRL sample $(0.26 \pm 0.01 \mathrm{mg} / \mathrm{g} \mathrm{dw})$.

Results showed significant differences between control bread and bread with vegetable flours, furthermore, the total phenolic content in breads was in all cases lower than in respective flour. Polyphenols are highly unstable species that are 
Table 2. Total phenolic content, total flavonoids content and antioxidant activity of flour and bread samples.

\begin{tabular}{|c|c|c|c|c|}
\hline \multirow[t]{2}{*}{ Sample } & \multirow[b]{2}{*}{$\begin{array}{l}\text { Total phenolic content } \\
\left(\mathrm{mg} \text { gallic acid } \mathrm{g}^{-1} \mathrm{dw}\right)\end{array}$} & \multirow[b]{2}{*}{$\begin{array}{l}\text { Total flavonoids content } \\
\left(\mathrm{mg} \text { quercetin } \mathrm{g}^{-1} \mathrm{dw}\right)\end{array}$} & \multicolumn{2}{|c|}{ Antioxidant activity } \\
\hline & & & $\begin{array}{c}\text { ABTS } \\
\left(m g \text { Trolox } \mathrm{g}^{-1} \mathrm{dw}\right)\end{array}$ & $\begin{array}{c}\text { DPPH } \\
\text { (\% Inhibition) }\end{array}$ \\
\hline F_CTRL & $0.29 \pm 0.00^{\mathrm{e}}$ & $0.14 \pm 0.02^{\mathrm{f}}$ & $0.26 \pm 0.02^{\mathrm{d}}$ & $3.94 \pm 0.10^{\mathrm{f}}$ \\
\hline F_BROC & $8.22 \pm 0.14^{\mathrm{b}}$ & $6.61 \pm 0.27^{b}$ & $8.58 \pm 0.33^{b}$ & $80.94 \pm 0.77^{\mathrm{b}}$ \\
\hline F_CAUL & $6.43 \pm 0.27^{c}$ & $3.83 \pm 0.58^{\mathrm{c}, \mathrm{d}}$ & $7.61 \pm 0.26^{\mathrm{b}}$ & $79.58 \pm 0.63^{\mathrm{b}}$ \\
\hline F_ART & $26.51 \pm 1.92^{\mathrm{a}}$ & $26.43 \pm 1.93^{\mathrm{a}}$ & $31.56 \pm 2.28^{\mathrm{a}}$ & $91.26 \pm 0.48^{\mathrm{a}}$ \\
\hline F_FEN & $4.54 \pm 0.08^{\mathrm{d}}$ & $2.04 \pm 0.13^{\mathrm{e}}$ & $5.90 \pm 0.42^{c}$ & $69.00 \pm 3.01^{\mathrm{c}}$ \\
\hline F_ZUC & $7.80 \pm 0.13^{b}$ & $4.56 \pm 0.52^{\mathrm{c}}$ & $8.59 \pm 0.33^{\mathrm{b}}$ & $47.27 \pm 2.95^{\mathrm{e}}$ \\
\hline F_MUSH & $6.11 \pm 0.53^{\mathrm{c}}$ & $2.48 \pm 0.31^{\mathrm{d}, \mathrm{e}}$ & $7.81 \pm 0.16^{\mathrm{b}}$ & $61.31 \pm 0.42^{\mathrm{d}}$ \\
\hline B_CTRL & $0.26 \pm 0.01^{\mathrm{d}}$ & $0.03 \pm 0.00^{\mathrm{d}}$ & $0.13 \pm 0.01^{\mathrm{e}}$ & $0.01 \pm 0.02^{\mathrm{d}}$ \\
\hline B_BROC & $2.44 \pm 0.04^{\mathrm{b}, \mathrm{c}}$ & $0.57 \pm 0.04^{\mathrm{b}}$ & $0.71 \pm 0.13^{\mathrm{b}, \mathrm{c}}$ & $5.73 \pm 0.18^{\mathrm{a}}$ \\
\hline B_CAUL & $2.45 \pm 0.08^{b, c}$ & $0.45 \pm 0.02^{\mathrm{c}}$ & $0.68 \pm 0.07^{c}$ & $4.22 \pm 0.28^{\mathrm{b}}$ \\
\hline B_ART & $2.50 \pm 0.01^{b}$ & $0.70 \pm 0.03^{\mathrm{a}}$ & $0.46 \pm 0.02^{\mathrm{d}}$ & $5.91 \pm 0.12^{\mathrm{a}}$ \\
\hline B_FEN & $2.45 \pm 0.03^{\mathrm{b}, \mathrm{c}}$ & $0.42 \pm 0.03^{c}$ & $0.56 \pm 0.08^{c, d}$ & $4.46 \pm 0.23^{\mathrm{b}}$ \\
\hline B_ZUC & $2.58 \pm 0.02^{\mathrm{a}}$ & $0.57 \pm 0.05^{\mathrm{b}}$ & $1.03 \pm 0.16^{\mathrm{a}}$ & $3.54 \pm 0.35^{c}$ \\
\hline B_MUSH & $2.40 \pm 0.04^{\mathrm{c}}$ & $0.45 \pm 0.06^{\mathrm{c}}$ & $0.87 \pm 0.16^{\mathrm{a}, \mathrm{b}}$ & $4.55 \pm 0.24^{\mathrm{b}}$ \\
\hline
\end{tabular}

${ }^{\mathrm{a}-\mathrm{f}}$ Means $( \pm \mathrm{SD}, \mathrm{n}=3)$ in the same column followed by different superscript letters differ significantly $(\mathrm{p}<0.05)$.

subject to numerous reactions in the course of food processing [13]. For baked products, such as bread, it is possible the occurrence of the degradation and loss of phenolic compounds due to the heat and oxidation during the mixing and baking process [14]. Some studies have reported the loss of antioxidants during mixing dough, knead and bake, arguing that the antioxidant active compounds present in flours might be damaged or degraded as a consequence of the heat/thermal process during baking [15]. In addition, Samaras, Camburn, Chandra, Gordon, and Ames [16] argued that the products of Maillard reaction during baking may be involved in the estimation of phenolic compounds, because caramelization products and polyphenolic oxidation products may have antioxidant activity but can also act as false positives in the estimation. In accordance with our results, also Holtekjølen et al. [14], Leenhardt et al. [15] and Chlopicka, Pasko, Gorinstein, Jedryas, and Zagrodzki [17] showed that the contents of phenols were lower in the experimental breads than in the respective flour. Han and Koh [18] observed a reduction of phenolic acids levels of about $20 \%-30 \%$ in breads in comparison to start material-enriched flour. In addition, they also showed that phenolics responsible for the antioxidant potential of enriched breads are already strongly bound to bread components at the stage of forming the bread mix and mixing the dough. Specifically, Leenhardt et al. [15] observed a loss of antioxidants during dough mixing and kneading. Other researchers suggested that antioxidant activity of breads could be modified by active oxidative enzymes presented in ingredients of compounds used in breads production [7]. Some studies have been performed to determine the impact of 
the bread-making process on the lipid-soluble antioxidant content of wheat and to understand the mechanisms responsible for the loss of these compounds; anyhow, a few strategies have been developed to preserve antioxidant compounds in bread [15].

Table 2 also shows the total flavonoids content in flour and bread, expressed as mg quercetin per gram of dry weight. The results showed that, as for the total phenols, also the content of total flavonoids was much higher in the F_ART sample $(26.43 \pm 1.93 \mathrm{mg} / \mathrm{g} \mathrm{dw})$ followed by F_BROC $(6.61 \pm 0.27 \mathrm{mg} / \mathrm{g} \mathrm{dw})$ and F_ZUC $(4.56 \pm 0.52 \mathrm{mg} / \mathrm{g} \mathrm{dw})$. The lowest value of flavonoids was detected in sample F_CTRL $(0.14 \pm 0.02 \mathrm{mg} / \mathrm{g} \mathrm{dw})$ and the differences were statistically significant among all samples. In all cases, the content of total flavonoids in flours was higher than in the breads. Specifically, the B_ART sample showed the greatest loss of flavonoids content compared to the corresponding flour. However, this sample showed the highest content of flavonoids $(0.70 \pm 0.03 \mathrm{mg} / \mathrm{g} \mathrm{dw}) \mathrm{re}-$ spect to the breads with addition of the other vegetable flours. Moreover, flavonoids content was lower in B_CTRL sample $(0.03 \pm 0.00 \mathrm{mg} / \mathrm{g} \mathrm{dw})$ and also in this case the results showed significant differences between control bread and bread with vegetable flours. According to the results presented, breads showed a much higher loss of flavonoids than the polyphenols, this may be due to the greater sensitivity of flavonoids at high baking temperatures. Thermal processing is generally considered to be destructive to nutrients, because most bioactive compounds become unstable when exposed to heat [19].

Comparing the flour types with the corresponding bread samples after the baking process, it is worth noting that the bread-making process created a loss of total flavonoids content. The low level of extractable bioactive compounds from bread after baking might be a result of formation of phenolic-containing complexes with polysaccharides and/or proteins/enzymes [20]. Sivam, Sun-Waterhouse, Perera, and Waterhouse [21] confirmed the existence of interactions between phenolics (especially flavonoids) and protein. In particular, flavonoids also interact with starch [22]. Zhang, Yang, Li, and Gao [23] showed that the solid complex of starch with quercetin leads to a reduction in starch digestibility via formation of resistant starch. These interactions may significantly influence the bioactivity of phenolic antioxidants and the bioaccessibility of starch and proteins in in vivo conditions.

In order to test the antioxidant activity of flour and bread two methods were used, ABTS and DPPH assays; for both, results are shown in Table 2. According to data obtained by ABTS assay, expressed as mg Trolox per gram of dry weight, as for phenols and flavonoids, also in this case F_ART sample showed significantly higher antioxidant activity $(31.56 \pm 2.28 \mathrm{mg} / \mathrm{g} \mathrm{dw})$ compared to all the other vegetable flours. In fact, Alonso, Guillen, Barroso, Puertas, and Garcia [24] reported that there is a positive correlation between total polyphenolic content and sample antioxidant activity. The second highest values were for F_ZUC $(8.59 \pm 0.33 \mathrm{mg} / \mathrm{g} \mathrm{dw})$ and F_BROC samples $(8.58 \pm 0.33 \mathrm{mg} / \mathrm{g} \mathrm{dw})$, while, among the vegetable flours, the sample F_FEN had the lowest antioxidant ac- 
tivity $(5.90 \pm 0.42 \mathrm{mg} / \mathrm{g} \mathrm{dw})$. Also in this case, F_CTRL sample had the lowest antioxidant activity $(0.26 \pm 0.02 \mathrm{mg} / \mathrm{g} \mathrm{dw})$. However, according to the data obtained, surprisingly, for bread with vegetable flours, the sample B_ART had the lowest antioxidant activity $(0.46 \pm 0.02 \mathrm{mg} / \mathrm{g} \mathrm{dw})$, while, B_ZUC sample, consistently with the above results, showed the highest value $(1.03 \pm 0.16 \mathrm{mg} / \mathrm{g} \mathrm{dw})$. These results could be explained, firstly, due to the considerable loss of the polyphenolic and flavonoid compounds, which has occurred among the artichoke flour and the corresponding bread, compared to all the other samples. Secondly, it is possible that the antioxidant activity of bread with the addition of zucchini flour was better reflected by the ABTS test compared to the bread with artichoke. Finally, B_CTRL sample showed the lowest antioxidant activity $(0.13 \pm 0.01$ $\mathrm{mg} / \mathrm{g} \mathrm{dw}$ ) with significant differences among all the bread samples.

$\mathrm{DPPH}$ assay was used as an additional method to determine the antioxidant activity of flour and bread samples. Specifically, the antioxidant capacity of the samples was evaluated based on scavenging capacity of free radical $\mathrm{DPPH}^{+}$. The antioxidant activity determined by DPPH test for flour and breads was expressed as percentage inhibition or percentage of discoloration. Antioxidant activity was highest in sample F_ART $(91.26 \% \pm 0.48 \%)$ followed by F_BROC $(80.94 \% \pm$ $0.77 \%)$, F_CAUL $(79.58 \% \pm 0.63 \%)$ and F_FEN samples $(69.00 \% \pm 3.01 \%)$. Surprisingly, F_ZUC sample had the lowest antioxidant activity $(47.27 \% \pm 2.95 \%)$.

For bread, the results largely showed the same trend of the flour, the antioxidant activity was higher in B_ART $(5.91 \% \pm 0.12 \%)$ and B_BROC samples $(5.73 \% \pm 0.18 \%)$, while the sample B_ZUC showed the lowest antioxidant activity $(3.54 \% \pm 0.35 \%)$. In addition, F_CTRL and B_CTRL samples had lower values of antioxidant activity with significant differences compared to all the other samples.

All these results suggest that there was a different trend in the antioxidant capacity of bread between ABTS and DPPH, but a similar one in the flours. Antioxidant capacity detected by ABTS test was significantly higher for bread with addition of zucchini flour compared to the value obtained with DPPH test. On the contrary, the DPPH assay showed a high antioxidant activity in bread with artichoke flour. Floegel, Kim, Chung, Koo, and Chun [25] reported that the correlation between the antioxidant capacity detected by ABTS and DPPH tests was higher in beverages and fruit but lower in vegetables. In particular, Kim, Lee, Lee, and Lee [26] described the difference between the two methods, specifying that the ABTS test is based on the generation of a blue/green color $\mathrm{ABTS}^{+}$, which is applicable to both hydrophilic and lipophilic antioxidant systems; while DPPH test uses a radical dissolved in organic media and it is applicable to hydrophobic systems. Furthermore, Chlopicka et al. [17] reported that the DPPH method is based on the evaluation of reducing ability of antioxidants to $\mathrm{DPPH}^{+}$, which is stable radical nitrogen, holding an odd-electron, therefore, steric accessibility is a determining factor of the analytical reaction. This explains why the DPPH assay is more sensitive to small molecules that have a good access to the radical site, and is less sensitive to larger molecules. 
Certainly, further studies will be necessary to deepen these issues, in order to establish the different composition and stability of the phenolic compounds present in the different vegetable flours. Finally, it can be noted that despite the loss of antioxidant compounds, during the baking processes, the bread samples enriched with vegetable flours showed a significant amount of polyphenolic and flavonoid compounds, with a higher antioxidant activity than in the control bread.

\subsubsection{Glycemic Response and Available Carbohydrates Content of Bread Samples}

Table 3 shows the glucose released during digestion for the investigated samples. As can be seen, a rapid release and significant differences of glucose were observed at 20,60 and $120 \mathrm{~min}$ following the addition of pancreatin and amyloglucosidase. In particular, the amount of glucose released from B_ART and B_ZUC samples was statistically lower than that of B_CTRL and the other samples. Anyway, at the end of the digestion (180 min) the B_CTRL sample recorded a highest release of glucose $(376.9 \pm 7.10 \mathrm{mg} \mathrm{GE} / \mathrm{g}$ bread). This behavior is reflected on the glycemic index determined on vegetable flour-fortified bread and B_CTRL samples (Figure 1). In fact, the incorporation of the vegetable flour at $15 \%$ caused a statistically significant decrease in glycemic index (GI) compared to the control sample, thereby contributing to elevate nutritional value of bread. Specifically, B_ART and B_ZUC samples recorded a lowest glycemic index (59 \pm 1.21 and $62 \pm 0.49$, respectively), thus confirming their content of glucose equivalent obtained at the end of the digestion process $(303.7 \pm 14.7$ and $295.4 \pm 9.80$ $\mathrm{mg} \mathrm{GE} / \mathrm{g}$ bread, respectively). It is conceivable that these results could be due to high dietary fiber content of vegetable flours used to enrich bread. In fact, Petitot, Barron, Morel, and Micard [27] have demonstrated that inclusion of dietary fibers would reduce blood glucose responses because of a slower absorption of glucose from the gastrointestinal tract, favoring lower susceptibility of starch to digestive enzymes. Finally, these finding appear to be related to the available carbohydrate content of the bread samples investigated (Figure 2). In fact, also in this case, B_ART and B_ZUC samples recorded the lowest ACH value content among samples (58.2 \pm 2.79 and $60.4 \pm 0.20 \mathrm{~g} \mathrm{ACH} / 100 \mathrm{~g}$ bread, respectively).

Table 3. Determination of glucose release of bread samples.

\begin{tabular}{cccccccc}
\hline $\begin{array}{c}\text { Digestion time } \\
(\mathrm{min})\end{array}$ & \multicolumn{7}{c}{$\begin{array}{c}\text { Glucose equivalent } \\
(\mathrm{mg} / \mathrm{g} \text { bread })\end{array}$} \\
\hline & B_CTRL & B_BROC & B_CAUL & B_ART & B_FEN & B_ZUC & B_MUSH \\
\hline 0 & $33.4 \pm 1.50^{\mathrm{a}}$ & $11.0 \pm 0.00^{\mathrm{f}}$ & $20.5 \pm 2.70^{\mathrm{d}}$ & $16.0 \pm 0.07^{\mathrm{e}}$ & $27.8 \pm 0.90^{\mathrm{c}}$ & $21.6 \pm 2.00^{\mathrm{d}}$ & $9.30 \pm 0.00^{\mathrm{f}}$ \\
20 & $108.9 \pm 5.60^{\mathrm{a}}$ & $73.6 \pm 6.00^{\mathrm{c}}$ & $84.0 \pm 7.60^{\mathrm{b}}$ & $58.7 \pm 4.80^{\mathrm{d}}$ & $88.7 \pm 6.70^{\mathrm{b}}$ & $54.7 \pm 2.70^{\mathrm{d}}$ & $116.1 \pm 2.90^{\mathrm{a}}$ \\
60 & $229.1 \pm 15.6^{\mathrm{a}}$ & $147.7 \pm 10.5^{\mathrm{b}}$ & $149.8 \pm 7.60^{\mathrm{b}}$ & $109.6 \pm 7.00^{\mathrm{c}}$ & $156.1 \pm 5.90^{\mathrm{b}}$ & $105.4 \pm 7.80^{\mathrm{c}}$ & $231.6 \pm 3.20^{\mathrm{a}}$ \\
120 & $350.2 \pm 2.40^{\mathrm{a}}$ & $238.7 \pm 5.80^{\mathrm{b}}$ & $264.4 \pm 10.3^{\mathrm{b}}$ & $188.9 \pm 6.80^{\mathrm{c}}$ & $242.3 \pm 15.0^{\mathrm{b}}$ & $157.7 \pm 10.1^{\mathrm{d}}$ & $266.4 \pm 17.9^{\mathrm{b}}$ \\
180 & $376.9 \pm 7.10^{\mathrm{a}}$ & $307.6 \pm 14.5^{\mathrm{c}, \mathrm{d}}$ & $320.1 \pm 13.4^{\mathrm{b}, \mathrm{c}}$ & $303.7 \pm 14.7^{\mathrm{c}, \mathrm{d}}$ & $315.5 \pm 3.20^{\mathrm{c}}$ & $295.4 \pm 9.80^{\mathrm{d}}$ & $338.6 \pm 6.20^{\mathrm{b}}$
\end{tabular}

${ }^{\mathrm{a}-\mathrm{f}}$ Means $( \pm \mathrm{SD}, \mathrm{n}=3)$ in the same row followed by different superscript letters differs significantly $(\mathrm{p}<0.05)$. 


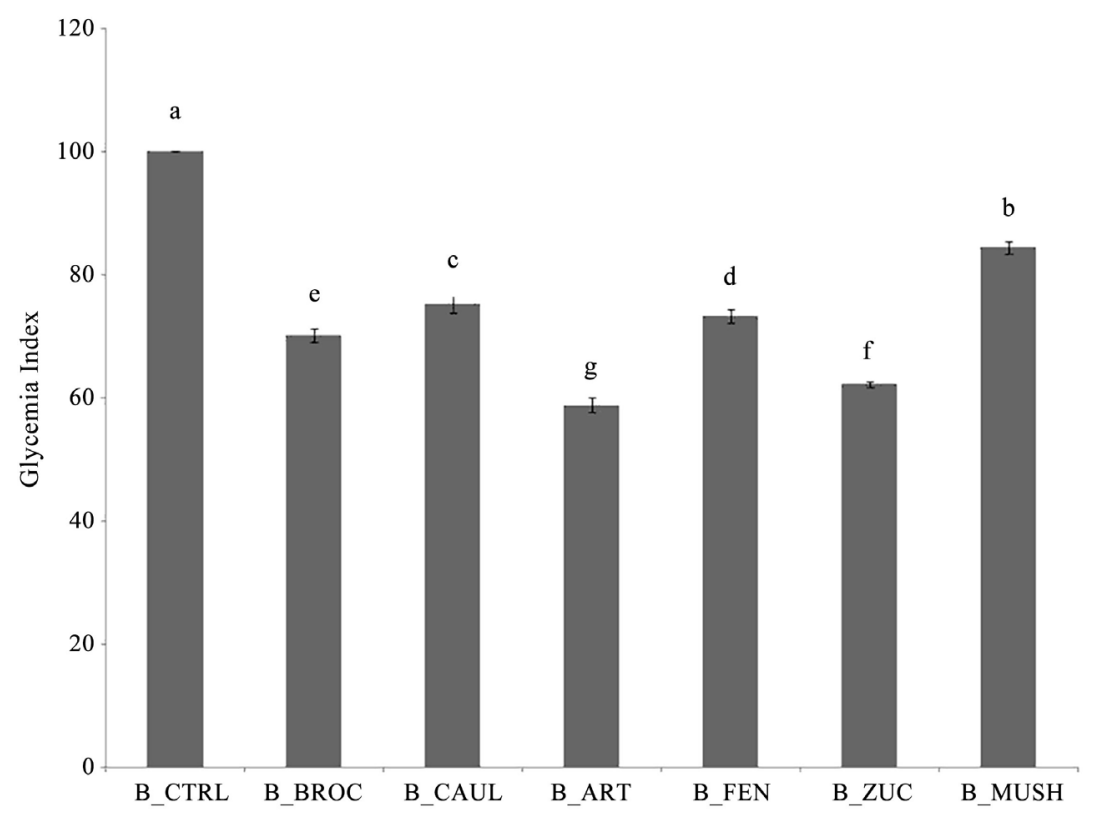

Figure 1. Glycemic response of bread samples: control bread (B_CTRL); broccoli flour bread (B_BROC); cauliflower flour bread (B_CAUL); artichoke flour bread (B_ART); fennel flour bread (B_FEN); zucchini flour bread (B_ZUC); mushroom flour bread (B_MUSH). Bars represent standard error of means $(\mathrm{n}=3)$ and means with different letters are significantly different $(\mathrm{P}<0.05)$.

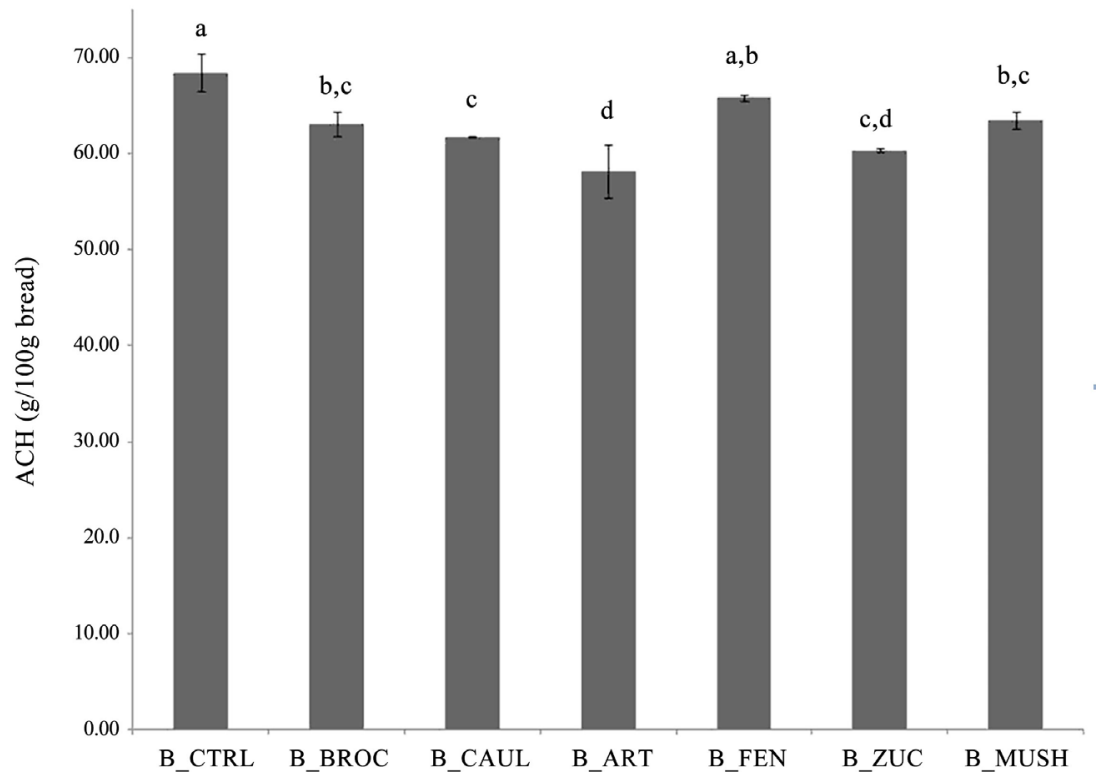

Figure 2. Available carbohydrates content $(\mathrm{ACH})$ of bread samples: control bread (B_CTRL); broccoli flour bread (B_BROC); cauliflower flour bread (B_CAUL); artichoke flour bread (B_ART); fennel flour bread (B_FEN); zucchini flour bread (B_ZUC); mushroom flour bread (B_MUSH). Bars represent standard error of means $(n=3)$ and means with different letters are significantly different $(\mathrm{P}<0.05)$.

\section{Conclusion}

The results obtained in this study indicated that the enrichment of gluten-free 
bread with different types of vegetable flours allowed the creation of bread with enhanced functional properties without adversely affecting the technological parameters. Results indicated that fennel flour gives the best results among the tested vegetable flours from a sensory point of view. Specifically, the B_FEN sample improved satisfactory all sensory bread properties and it showed the higher scores with statistically significant differences compared to all the other samples, including also the control bread. As regards chemical composition, all the enriched bread samples showed very good functional properties respect to the control sample. In particular, B_ART and B_ZUC samples have high content of phenolic compounds, though they need to be improved from the sensory point of view. The GI of all enriched bread samples was lower respect to the control sample, and also in this case, B_ART and B_ZUC were the best samples. These results indicate that vegetable flours can be effectively incorporated in gluten-free bread to improve the functional properties, and reduce the glycemic index without affecting the sensory quality.

\section{References}

[1] Sakač, M., Torbica, A., Sedej, I. and Hadnađev, M. (2011) Influence of Breadmaking on Antioxidant Capacity of Gluten Free Breads Based on Rice and Buckwheat Flours. Food Research International, 44, 2806-2813. https://doi.org/10.1016/j.foodres.2011.06.026

[2] Phimolsiripol, Y., Mukprasirt, A. and Schoenlechner, R. (2012) Quality Improvement of Rice-Based Gluten-Free Bread Using Different Dietary Fibre Fractions of Rice Bran. Journal of Cereal Science, 56, 389-395. https://doi.org/10.1016/j.jcs.2012.06.001

[3] Lazaridou, A., Duta, D., Papageorgiou, M., Belc, N. and Biliaderis, C.G. (2007) Effects of Hydrocolloids on Dough Rheology and Bread Quality Parameters in Gluten-Free Formulations. Journal of Food Engineering, 79, 1033-1047. https://doi.org/10.1016/j.jfoodeng.2006.03.032

[4] Sciarini, L. S., Ribotta, P.D., León, A.E. and Pérez, G.T. (2010) Influence of Gluten-Free Flours and Their Mixtures on Batter Properties and Bread Quality. Food and Bioprocess Technology, 3, 577-585. https://doi.org/10.1007/s11947-008-0098-2

[5] Padalino, L., Mastromatteo, M., Lecce, L., Cozzolino, F. and Del Nobile, M.A. (2013) Manufacture and Characterization of Gluten-Free Spaghetti Enriched with Vegetable Flour. Journal of Cereal Science, 57, 333-342. https://doi.org/10.1016/j.jcs.2012.12.010

[6] Yoo, K.M., Lee, C.H., Lee, H., Moon, B. and Lee, C.Y. (2008) Relative Antioxidant and Cytoprotective Activities of Common Herbs. Food Chemistry, 106, 929-936. https://doi.org/10.1016/j.foodchem.2007.07.006

[7] Das, L., Raychaudhuri, U. and Chakraborty, R. (2013) Herbal Fortification of Bread with Fennel Seeds. Food Technology and Biotechnology, 51, 434-440.

[8] Lim, H.S., Park, S.H., Ghafoor, K., Hwang, S.Y. and Park, J. (2011) Quality and Antioxidant Properties of Bread Containing Turmeric (Curcuma longa L.) Cultivated in South Korea. Food Chemistry, 124, 1577-1582. https://doi.org/10.1016/j.foodchem.2010.08.016

[9] Marinelli, V., Padalino, L., Nardiello, D., Del Nobile, M.A. and Conte, A. (2015) New Approach to Enrich Pasta with Polyphenols from Grape Marc. Journal of 
Chemistry, Article ID: 734578. https://doi.org/10.1155/2015/734578

[10] Cedola, A., Cardinali, A., Del Nobile, M.A. and Conte, A. (2017) Fish Burger Enriched by Olive Oil Industrial By-Product. Food Science and Nutrition, 5, 837-844. https://doi.org/10.1002/fsn3.461

[11] Mastromatteo, M., Danza, A., Lecce, L., Spinelli, S., Lampignano, V., Laverse, J. and Del Nobile, M.A. (2014) Effect of Durum Wheat Varieties on Bread Quality. International Journal of Food Science \& Technology, 49, 72-81. https://doi.org/10.1111/ijfs. 12276

[12] Chillo, S., Laverse, J., Falcone, P.M., Protopapa, A. and Del Nobile, M.A. (2008) Influence of the Addition of Buckwheat Flour and Durum Wheat Bran on Spaghetti Quality. Journal of Cereal Science, 47, 144-152. https://doi.org/10.1016/j.jcs.2007.03.004

[13] Cheynier, V. (2005) Polyphenols in Foods Are More Complex than Often Thought. American Journal of Clinical Nutrition, 81, 223-229. https://doi.org/10.1093/ajcn/81.1.223S

[14] Holtekjølen, A.K., Bævre, A.B., Rødbotten, M., Berg, H. and Knutsen, S.H. (2008) Antioxidant Properties and Sensory Profiles of Breads Containing Barley Flour. Food Chemistry, 110, 414-421. https://doi.org/10.1016/j.foodchem.2008.02.054

[15] Leenhardt, F., Lyan, B., Rock, E., Boussard, A., Potus, J., Chanliaud, E. and Remesy, C. (2006) Wheat Lipoxygenase Activity Induces Greater Loss of Carotenoids than Vitamin E during Breadmaking. Journal of Agriculture and Food Chemistry, 54, 1710-1715. https://doi.org/10.1021/jf052243m

[16] Samaras, T.S., Camburn, P.A., Chandra, S.X., Gordon, M.H. and Ames, J.M. (2005) Antioxidant Properties of Kilned and Roasted Malts. Journal of Agriculture and Food Chemistry, 53, 8068-8074. https://doi.org/10.1021/jf051410f

[17] Chlopicka, J., Pasko, P., Gorinstein, S., Jedryas, A. and Zagrodzki, P. (2012) Total Phenolic and Total Flavonoid Content, Antioxidant Activity and Sensory Evaluation of Pseudocereal Breads. LWT-Food Science and Technology, 46, 548-555. https://doi.org/10.1016/j.lwt.2011.11.009

[18] Han, H.M. and Koh, B.K. (2011) Antioxidant Activity of Hard Wheat Flour, Dough and Bread Prepared Using Various Processes with the Addition of Different Phenolic Acids. Journal of the Science of Food and Agriculture, 91, 604-608. https://doi.org/10.1002/jsfa.4188

[19] Swieca, M., Gawlik-Dziki, U., Dziki, D., Baraniak, B. and Czyz, J. (2013) The Influence of Protein-Flavonoid Interactions on Protein Digestibility in Vitro and the Antioxidant Quality of Breads Enriched with Onion Skin. Food Chemistry, 141, 451-458. https://doi.org/10.1016/j.foodchem.2013.03.048

[20] Sun-Waterhouse, D., Chen, J., Chuah, C., Wibisono, R., Melton, L. D., Laing, W., et al. (2009) Kiwifruit-Based Polyphenols and Related Antioxidants for Functional Foods: Kiwifruit Extract-Enhanced Gluten-Free Bread. International Journal of Food Science and Nutrition, 60, 251-264. https://doi.org/10.1080/09637480903012355

[21] Sivam, A.S., Sun-Waterhouse, D., Perera, C.O. and Waterhouse, G.I.N. (2013) Application of FT-IR and Raman Spectroscopy for the Study of Biopolymers in Breads Fortified with Fibre and Polyphenols. Food Research International, 50, 574-585. https://doi.org/10.1016/j.foodres.2011.03.039

[22] Singh, J., Dartois, A. and Kaur, L. (2010) Starch Digestibility in Food Matrix: A Review. Trends in Food Science \& Technology, 21, 168-180.

https://doi.org/10.1016/j.tifs.2009.12.001 
[23] Zhang, L., Yang, X., Li, S. and Gao, W. (2011) Preparation, Physicochemical Characterization and in Vitro Digestibility on Solid Complex of Maize Starches with Quercetin. LWT-Food Science and Technology, 44, 787-792.

https://doi.org/10.1016/j.lwt.2010.09.001

[24] Alonso, A.M., Guillen, D.A., Barroso, C.G., Puertas, B. and Garcia, A. (2002) Determination of Antioxidant Activity of Wine Byproducts and Its Correlation with Polyphenolic Content. Journal of Agricultural and Food Chemistry, 50, 5832-5836. https://doi.org/10.1021/jf025683b

[25] Floegel, A., Kim, D.O., Chung, S.J., Koo, S.I. and Chun, O.K. (2011) Comparison of ABTS/DPPH Assays to Measure Antioxidant Capacity in Popular Antioxidant-Rich US Foods. Journal of Food Composition and Analysis, 24, 1043-1048. https://doi.org/10.1016/j.jfca.2011.01.008

[26] Kim, D.O., Lee, K.W., Lee, H.J. and Lee, C.Y. (2002) Vitamin C Equivalent Antioxidant Capacity (VCEAC) of Phenolic Phytochemicals. Journal of Agriculture and Food Chemistry, 50, 3713-3717. https://doi.org/10.1021/jf020071c

[27] Petitot, M., Barron, C., Morel, M.H. and Micard, V. (2010) Impact of Legume Flour Addition on Pasta Structure: Consequences on Its in Vitro Starch Digestibility. Food Biophysics, 5, 284-299. https://doi.org/10.1007/s11483-010-9170-3 